\title{
Karakteristik Klinis dan Status Nutrisi pada Pasien Stroke Fase Akut
}

\author{
Lisda Amalia, Arviana Adamantina Putri \\ Departemen Neurologi,Fakultas Kedokteran Universitas Padjadjaran-RSUP Dr. Hasan Sadikin Bandung
}

\begin{abstract}
Abstrak
Latar Belakang dan Tujuan: Disabilitas yang berat pada stroke meningkatkan risiko terjadinya malnutrisi. Malnutrisi pada pasien stroke dapat disebabkan oleh defisit neurologis dan faktor risiko. Malnutrisi pada stroke meningkatkan morbiditas dan mortalitas. Penelitian ini bertujuan untuk mengetahui karakteristik klinis dan status nutrisi pasien stroke.

Subjek dan Metode: Penelitian bersifat deskriptif retrospektif pada pasien stroke yang dirawat di RSUP Hasan Sadikin Bandung pada periode 1 Agustus 2020 hingga 30 September 2020. Status nutrisi dinilai menggunakan Indeks Massa Tubuh (IMT) dan skor Subjective Global Assessment (SGA). IMT dihitung menggunakan kg/ m2, dikelompokkan menjadi obesitas (IMT >30), overweight (IMT 25,0-29,9), normal (IMT 18,5-24,9) dan underweight (IMT $<18,5)$. Skor SGA $<2$ termasuk nutrisi baik, dan $\geq 2$ tergolong malnutrisi.

Hasil: Didapatkan 52 orang pasien stroke yang sebagian besar berjenis kelamin laki-laki (57,7\%) dengan rentang usia 38-86 tahun (rata-rata 57 tahun), 51,9\% mengalami malnutrisi berdasarkan skor SGA, IMT normal dan overweight sebanyak 23 (44,2\%) orang, diikuti obesitas (5,7\%) dan underweight (5,7\%). Ditemukan 71,4\% usia $\geq 65$ tahun mengalami malnutrisi. Kondisi malnutrisi didominasi pasien stroke infark kardioemboli $(63,6 \%)$, dengan derajat stroke berat (58,3\%), disfagia (59,4\%), dengan komorbid infeksi (71,4\%) dan stress ulcer (55,6\%). Simpulan: Berdasarkan penelitian ini, didapatkan bahwa usia tua, derajat stroke sedang-berat, komorbid infeksi dan stress ulcer akan memiliki kecenderungan malnutrisi sehingga penanganan stroke yang baik dapat menurunkan risiko terjadinya malnutrisi. Kejadian stroke berulang tidak menjadi risiko terjadinya malnutrisi pada penelitian ini.
\end{abstract}

Kata kunci: fase akut, karakteristik klinis, status nutrisi, stroke

JNI 2022; $11(1): 1-6$

\section{Clinical Characteristics and Nutrition Status in Acute Stroke Patients}

\begin{abstract}
Background and Objective: Severe disability in stroke increase the risk of malnutrition. Malnutrition in stroke patients can be caused by neurological deficits and risk factors. Malnutrition in stroke increases morbidity and mortality. This study aims to determine the clinical characteristics and nutritional status of stroke patients.

Subject and Methods: This study was a retrospective descriptive study of stroke patients who were treated in the Neurology ward of Hasan Sadikin Hospital Bandung from 1 August 2020 to 30 September 2020. Nutritional status was assessed using Body Mass Index (BMI) and Subjective Global Assessment (SGA) scores. BMI was calculated using $\mathrm{kg} / \mathrm{m} 2$, grouped into obese (BMI> 30), overweight (BMI 25.0-29.9), normal (BMI 18.5-24.9) and underweight $(\mathrm{BMI}<18.5)$. SGA score $<2$ is considered as good nutrition, and $\geq 2$ is classified as malnutrition. Results: There were 52 stroke patients, most of them were male (57.7\%) with an age range of 38-86 years old (mean 57 years), 51.9\% were malnourished based on the SGA score, normal BMI and overweight were $23(44.2 \%)$ people, followed by obesity (5.7\%) and underweight (5.7\%). We also found $71.4 \%$ aged $\geq 65$ years are malnourished. This condition was dominated by cardioembolic stroke patients $(63.6 \%)$, with severe stroke $(58.3 \%)$, dysphagia (59.4\%), with comorbid infections (71.4\%) and stress ulcers $(55.6 \%)$.

Conclusion: Based on this study, it was found that elderly, moderate-severe stroke, comorbid infections and stress ulcers have a tendency related to malnutrition. Good or better management can/indeed reduce the risk of malnutrition. Stroke history was not a risk for malnutrition in this study.
\end{abstract}

Key words: acute phase, clinical characteristics, nutritional status, stroke

JNI 2022; 11 (1): 1-6 


\section{Pendahuluan}

Stroke adalah penyebab kematian pertama di Indonesia serta merupakan salah satu penyebab utama disabilitas di dunia. ${ }^{1-3}$ Angka kematian dalam 30 hari pertama dan pada 1 tahun setelah stroke masing-masingnya adalah $20 \%$ dan $30 \% .{ }^{4}$ American Heart Association (AHA) menyatakan bahwa angka kejadian stroke yaitu 3 juta pasien stroke per tahun dan 50.000 pasien stroke serangan awal terjadi pertahun. ${ }^{5}$ Lima ratus ribu kasus stroke di Indonesia dengan 125.000 diantaranya meninggal dunia. ${ }^{1}$ Sembilan puluh persen penderita stroke mengalami disabilitas di masa kehidupannya. ${ }^{6}$ Disabilitas yang berat pada stroke akan meningkatkan risiko terjadinya malnutrisi. Prevalensi malnutrisi pada stroke fase akut yaitu $8-34 \% .{ }^{4,7}$

Malnutrisi pada pasien stroke dapat disebabkan oleh defisit neurologis seperti penurunan kesadaran, paresis saraf otak, hemiparesis/ hemiplegia, dan adanya disfagia. ${ }^{4}$ Malnutrisi pada pasien stroke meningkatkan morbiditas dan mortalitas. Malnutrisi terjadi karena adanya ketidakseimbangan antara kebutuhan energi yang meningkat dengan asupan energi dan protein yang tidak adekuat. ${ }^{4}$ Selama fase akut dan pemulihan pada pasien stroke, intervensi gizi khusus melalui upaya tim multidisiplin dapat meningkatkan pemulihan fungsi neurokognitif. Identifikasi dini dan pengelolaan malnutrisi dengan modifikasi diet atau strategi terapi khusus untuk memastikan asupan gizi yang memadai haruslah mendapat perhatian lebih, karena status gizi buruk dapat memperburuk kerusakan otak dan berkontribusi pada prognosis yang buruk. ${ }^{8}$

Alat yang divalidasi diperlukan untuk mengevaluasi secara berkala keberadaan malnutrisi pada pasien stroke dari awal masuk hingga perencanaan pulang. Kondisi gizi buruk dapat dinilai dengan menggunakan beberapa parameter seperti: penurunan berat badan, penurunan asupan oral, dan atrofi otot serta derajat kehilangan lemak subkutan. ${ }^{9}$ Penelitian ini bertujuan untuk mengetahui karakteristik klinis dan status nutrisi pada pasien stroke fase akut di Rumah Sakit Hasan Sadikin Bandung.

\section{Metode}

Penelitian bersifat deskriptif retrospektif. Populasi penelitian adalah semua pasien stroke yang dirawat di bangsal neurologi Rumah Sakit Hasan Sadikin Bandung dalam periode 1 Agustus 2020 hingga 30 September 2020 yang mempunyai data rekam medis lengkap, berupa identitas pasien, skor National Institute of Health Stroke Scale (NIHSS), karakteristik defisit neurologis, komorbid dan data laboratorium termasuk status nutrisi. Jumlah pasien stroke yang dirawat selama periode tersebut adalah 52 orang, dan semuanya memiliki data rekam medis yang lengkap yang dapat dimasukan dalam penelitian. Sampel penelitian adalah semua populasi penelitian.

Status nutrisi dinilai menggunakan Indeks Massa Tubuh (IMT) dan skor Subjective Global Assessment (SGA). IMT dihitung menggunakan $\mathrm{kg} / \mathrm{m} 2$, dikelompokkan menjadi obesitas (IMT $>30$ ), overweight (IMT 25,0-29,9), normal (IMT $18,5-24,9$ ) dan underweight (IMT $<18,5$ ). Skor SGA $<2$ termasuk nutrisi baik, dan $\geq 2$ tergolong malnutrisi. Usia digolongkan menjadi kurang dari 65 tahun, dan lebih dari 65 tahun berdasarkan faktor risiko tinggi terjadinya stroke pada AHA 2019. ${ }^{5}$ Penelitian ini telah disetujui oleh tim Komite Etik Penelitian Kesehatan Rumah Sakit Umum Pusat Hasan Sadikin Bandung dengan nomor LB.02.01/X.6.5/314/2020.

\section{Hasil}

\section{Data Demografis dan Karakteristik Klinis}

Selama penelitian didapatkan 52 orang pasien stroke yang dirawat di bangsal neurologi Rumah Sakit Hasan Sadikin Bandung. Data demografis dan karakteristik klinis dengan status gizi dan nutrisinya ditunjukan pada tabel 1 . Rata-rata usia pasien adalah 57 tahun, dengan $30(57,7 \%)$ orang merupakan laki-laki. Sebanyak 27 (51,9\%) orang mengalami malnutrisi, status gizi normal dan overweight sebanyak 23 (44,2\%) orang, diikuti obesitas (5,7\%) dan underweight (5,7\%). Stroke didominasi oleh stroke infark $(63,5 \%)$ dengan sebagian besar disebabkan proses aterotrombotik atau tromboemboli (66,7\%). Berdasarkan skor National Institute of Health Stroke Scale 
Tabel 1. Karakteristik Klinis Pasien

\begin{tabular}{|c|c|c|c|c|c|c|c|}
\hline \multirow[t]{2}{*}{ Kategori } & \multirow{2}{*}{$\begin{array}{l}\text { Total } \\
(\mathrm{N}=52)(\%)\end{array}$} & \multicolumn{3}{|l|}{ IMT } & \multicolumn{3}{|l|}{ Skor SGA } \\
\hline & & $\begin{array}{l}\text { Obesitas } \\
(\mathrm{N}=3)(\%)\end{array}$ & $\begin{array}{l}\text { Overweight } \\
(N=23)(\%)\end{array}$ & $\begin{array}{l}\text { Normal } \\
(\mathrm{N}=23)(\%)\end{array}$ & $\begin{array}{l}\text { Underweight } \\
(\mathrm{N}=3)(\%)\end{array}$ & $\begin{array}{l}<2 \\
(N=25)(\%)\end{array}$ & $\begin{array}{l}\geq 2 \\
(\mathrm{~N}=27)(\%)\end{array}$ \\
\hline Usia, rata-rata, th & $57(38-86)$ & & & & & & \\
\hline$<65$ & $38(73,1)$ & $2(5,3)$ & $16(42,1)$ & $19(50)$ & $1(2.6)$ & $21(55,3)$ & $17(44,7)$ \\
\hline$\geq 65$ & $14(26,9)$ & $1(7,1)$ & $7(50)$ & $4(28,6)$ & $2(14,3)$ & $4(28,6)$ & $10(71,4)$ \\
\hline \multicolumn{8}{|l|}{ Jenis kelamin } \\
\hline Laki-laki & $30(57,7)$ & $3(10)$ & $12(40)$ & $13(43,3)$ & $2(6,7)$ & $13(43,3)$ & $17(56,7)$ \\
\hline Perempuan & $22(42,3)$ & 0 & $11(50)$ & $10(45,5)$ & $1(4,5)$ & $12(54,5)$ & $10(45,5)$ \\
\hline \multicolumn{8}{|l|}{ Stroke } \\
\hline Infark & $33(63,5)$ & $1(3)$ & $15(45,5)$ & $15(45,5)$ & $2(6)$ & $16(48,5)$ & $17(51,5)$ \\
\hline $\mathrm{AT} / \mathrm{TE}$ & $22(66,7)$ & $1(4,5)$ & $9(40,9)$ & $11(50)$ & $1(4,5)$ & $12(54,5)$ & $10(45,5)$ \\
\hline $\mathrm{KE}$ & $11(33,3)$ & 0 & $6(54,5)$ & $4(36,5)$ & $1(9)$ & $4(36,4)$ & $7(63,6)$ \\
\hline Perdarahan & $19(36,5)$ & $2(10,5)$ & $8(42,1)$ & $8(42,1)$ & $1(5,3)$ & $9(47,4)$ & $10(52,6)$ \\
\hline \multicolumn{8}{|l|}{ Stroke } \\
\hline $\begin{array}{l}\text { Serangan } \\
\text { pertama }\end{array}$ & $33(63,5)$ & $1(3)$ & $13(39,4)$ & $17(51,5)$ & $2(6)$ & $15(45,5)$ & $18(54,5)$ \\
\hline Berulang & $19(36,5)$ & $1(5,3)$ & $10(52,6)$ & $7(36,8)$ & $1(5,3)$ & $11(57,9)$ & $8(42,1)$ \\
\hline \multicolumn{8}{|l|}{ NIHSS } \\
\hline Ringan & $7(13,5)$ & 0 & $3(42,9)$ & $3(42,9)$ & $1(14,3)$ & $4(57,1)$ & $3(42,9)$ \\
\hline Sedang & $33(63,5)$ & $3(9,1)$ & $12(36,4)$ & $18(54,5)$ & 0 & $18(54,5)$ & $15(45,5)$ \\
\hline Berat & $12(23)$ & 0 & $7(58,3)$ & $3(25)$ & $2(16,6)$ & $5(41,7)$ & $7(58,3)$ \\
\hline $\begin{array}{l}\text { Sangat } \\
\text { berat }\end{array}$ & 0 & 0 & 0 & 0 & 0 & 0 & 0 \\
\hline \multicolumn{8}{|l|}{ Gejala } \\
\hline Hemiparese & $26(50)$ & $2(7,7)$ & $6(23,1)$ & $17(65,4)$ & $1(3,8)$ & $11(42,3)$ & $15(57,7)$ \\
\hline Hemiplegia & $15(28,8)$ & 0 & $10(66,7)$ & $5(33,3)$ & 0 & $9(60)$ & $6(40)$ \\
\hline Tetraparese & $9(17,3)$ & $1(11,1)$ & $6(66,7)$ & $1(11,1)$ & $1(11,1)$ & $5(55,6)$ & $4(44,4)$ \\
\hline Lateralisasi (-) & $2(3,8)$ & 0 & $1(50)$ & 0 & $1(50)$ & 0 & $2(100)$ \\
\hline Disfagia & $32(61,5)$ & $1(3,1)$ & $14(43,8)$ & $14(43,8)$ & $3(9,3)$ & $13(40,6)$ & $19(59,4)$ \\
\hline \multicolumn{8}{|l|}{ Faktor Risiko* } \\
\hline Hipertensi & 38 & $2(5.3)$ & $18(47.4)$ & $17(44.7)$ & $1(2.6)$ & $21(55,3)$ & $17(44.7)$ \\
\hline $\begin{array}{l}\text { Diabetes } \\
\text { Mellitus }\end{array}$ & 8 & $1(12.5)$ & $5(62.5)$ & $1(12.5)$ & $1(12.5)$ & $4(50)$ & $4(50)$ \\
\hline Dislipidemia & 34 & $3(8,8)$ & $18(52,9)$ & $13(38,3)$ & 0 & $20(58,8)$ & $14(41,2)$ \\
\hline Merokok & 3 & 0 & $1(33,3)$ & $2(66,7)$ & 0 & $1(33,3)$ & $2(66,7)$ \\
\hline $\begin{array}{l}\text { Kelainan } \\
\text { Jantung }\end{array}$ & 11 & 0 & $6(54,5)$ & $4(36,4)$ & $1(9,1)$ & $4(36,4)$ & $7(63,6)$ \\
\hline \multicolumn{8}{|l|}{ Komorbid* } \\
\hline CKD & 2 & 0 & $2(100)$ & 0 & 0 & $1(50)$ & $1(50)$ \\
\hline AKI & 7 & $1(14,2)$ & $3(42,9)$ & $3(42,9)$ & 0 & $4(57,1)$ & $3(42,9)$ \\
\hline Infeksi & 7 & 0 & $2(28,6)$ & $2(28,6)$ & $3(42,9)$ & $2(28.6)$ & $5(71.4)$ \\
\hline Stress Ulcer & 9 & 0 & $4(44,4)$ & $5(55,6)$ & 0 & $4(44,4)$ & $5(55,6)$ \\
\hline Kondisi lain** & 8 & $1(12,5)$ & $5(62,5)$ & $2(25)$ & 0 & $3(37,5)$ & $5(62,5)$ \\
\hline
\end{tabular}

Keterangan : IMT: Indeks Massa Tubuh; SGA: Subjective Global Assesment; CKD: Chronic Kidney Disease; AKI: Acute Kidney Injury; NIHSS: National Institutes Health Stroke Scale, *satu pasien dapat memiliki lebih dari satu faktor risiko dan komorbid

** Kondisi lain, meliputi kehamilan, dehidrasi, hipoglikemia dan asma bronchiale 
Tabel 2. Hasil Laboratorium Status Nutrisi Subjek Penelitian

\begin{tabular}{|c|c|c|c|c|c|c|c|}
\hline \multirow[t]{3}{*}{ Laboratorium } & \multicolumn{7}{|c|}{ Rata-rata (maks-min) } \\
\hline & \multirow{2}{*}{$\begin{array}{l}\text { Total } \\
(\mathrm{N}=52)\end{array}$} & \multicolumn{3}{|c|}{ Status Gizi } & \multicolumn{3}{|c|}{ Status Nutrisi } \\
\hline & & Obesitas & Overweight & Normal & Underweight & Baik & Malnutrisi \\
\hline $\begin{array}{l}\text { Kolesterol } \\
\text { Total }\end{array}$ & $\begin{array}{l}206,5(115- \\
268)\end{array}$ & $\begin{array}{l}222 \\
(215-229)\end{array}$ & $\begin{array}{l}191,6 \\
(115-234)\end{array}$ & $\begin{array}{l}206,7 \\
(148-268)\end{array}$ & $\begin{array}{l}182,3(153- \\
200)\end{array}$ & $\begin{array}{l}200,6 \\
(115-268)\end{array}$ & $\begin{array}{l}199,9(126- \\
260)\end{array}$ \\
\hline HDL & $40(20-74)$ & $\begin{array}{l}42 \\
(38-48)\end{array}$ & $41(20-74)$ & $43(25-61)$ & $39(37-41)$ & $\begin{array}{l}41 \\
(22-65)\end{array}$ & $\begin{array}{l}42 \\
(20-74)\end{array}$ \\
\hline LDL & $\begin{array}{l}131(59- \\
256)\end{array}$ & $\begin{array}{l}132 \\
(101-165)\end{array}$ & $\begin{array}{l}121(59- \\
256)\end{array}$ & $\begin{array}{l}131(73- \\
191)\end{array}$ & $125(99-140)$ & $\begin{array}{l}128 \\
(59-256)\end{array}$ & $\begin{array}{l}127 \\
(73-174)\end{array}$ \\
\hline Trigliserida & $\begin{array}{l}116(27- \\
559)\end{array}$ & $\begin{array}{l}134 \\
(80-195)\end{array}$ & $\begin{array}{l}141(27- \\
559)\end{array}$ & $\begin{array}{l}142(38- \\
419)\end{array}$ & $87(83-95)$ & $\begin{array}{l}161 \\
(38-559)\end{array}$ & $\begin{array}{l}114 \\
(27-212)\end{array}$ \\
\hline Asam Urat & $\begin{array}{l}5,4(1,7- \\
12,5)\end{array}$ & $7(5.4-9.5)$ & $\begin{array}{l}5,4(2,1- \\
12.5)\end{array}$ & $\begin{array}{l}5.8(2.2- \\
9.6)\end{array}$ & $3,2(1,7-5,3)$ & $\begin{array}{l}5,7 \\
(2.2-9.6)\end{array}$ & $\begin{array}{l}5,4 \\
(1.7-12.5)\end{array}$ \\
\hline GDS & $\begin{array}{l}131(12- \\
611)\end{array}$ & $\begin{array}{l}215 \\
(99-310)\end{array}$ & $\begin{array}{l}164(12- \\
358)\end{array}$ & $\begin{array}{l}137(85- \\
358)\end{array}$ & $\begin{array}{l}297(144- \\
611)\end{array}$ & $\begin{array}{l}158(85- \\
358)\end{array}$ & $\begin{array}{l}165 \\
(12-611)\end{array}$ \\
\hline $\mathrm{HbA1C}$ & $7,7(5-11)$ & $8,5(6-11)$ & $8(7-11)$ & $7(6-10)$ & $5(5)$ & $8(6-11)$ & $8(5-11)$ \\
\hline
\end{tabular}

(NIHSS), didapatkan pasien dengan derajat stroke sedang sebanyak $33(63,5 \%)$ orang diikuti derajat stroke berat (23\%) dan ringan (13,5\%). $33(63,5 \%)$ orang mengalami serangan pertama stroke. Gejala yang muncul sebagian besar adalah hemiparese $(50 \%)$ dengan $32(61,5 \%)$ orang mengalami disfagia. Terdapat 2 pasien tanpa tanda lateralisasi, dan keduanya mengalami perdarahan subaraknoid. Faktor risiko stroke didominasi oleh hipertensi sebanyak 38 orang diikuti dislipidemia sebanyak 34 orang. Komorbid yang dapat memperberat luaran pada pasien stroke antara lain stress ulcer, gangguan fungsi ginjal, infeksi, dan kondisi lainnya seperti kehamilan, dehidrasi, hipoglikemia dan asma bronchiale.

Sebanyak 9 orang mengalami stress ulcer, diikuti dengan komorbid kondisi lain, infeksi, penyakit ginjal akut dan gagal ginjal kronis. Kondisi malnutrisi sebagian besar ada pada grup dengan komorbid infeksi $(71,4 \%)$, dalam penelitian ini jenis infeksi yang muncul yaitu, 5 pasien pneumonia, 1 pasien diare akut dan 1 pasien ulkus dekubitus. Berdasarkan skor Subjective Global Assessment (SGA) didapatkan sebanyak $27(51,9 \%)$ orang mengalami malnutrisi, terutama pada usia $\geq 65$ tahun $(71,4 \%)$. Sebagian besar pasien malnutrisi dengan derajat stroke berat $(58,3 \%)$, dan gejala stroke disertai disfagia
$(59,4 \%)$ serta pasien dengan komorbid infeksi $(71,4 \%)$.

\section{Laboratorium Faktor Risiko Vaskular}

Tabel 2 menunjukan hasil laboratorium faktor risiko vaskular berdasarkan status gizi dan status nutrisinya. Nilai tertinggi dari kolesterol total $(268 \mathrm{mg} / \mathrm{dL})$ terdapat pada grup dengan status gizi normal dan status nutrisi baik. Nilai tertinggi untuk LDL $(256 \mathrm{mg} / \mathrm{dL})$ dan trigliserida (559 $\mathrm{mg} / \mathrm{dL}$ ) terdapat pada grup dengan status gizi overweight. Pada grup malnutrisi didapatkan nilai terendah $(12 \mathrm{mg} / \mathrm{dL})$ dan tertinggi $(622 \mathrm{mg} /$ dL) untuk GDS. HbA1C tertinggi $(11 \mathrm{mg} / \mathrm{dL})$ terdapat pada grup dengan status gizi obesitas dan overweight, serta pada grup status nutrisi baik dan juga malnutrisi.

\section{Pembahasan}

Hasil dari penelitian ini, memberikan keterangan status gizi dan status nutrisi pada pasien stroke yang dirawat di bangsal neurologi Rumah Sakit Hasan Sadikin dalam periode 1 Agustus 2020 hingga 30 September 2020. Didapatkan 52 pasien dalam penelitian ini, status gizi overweight dan normal masing-masing sebanyak $23(44,2 \%)$ orang, diikuti obesitas dan underweight masingmasing sebanyak $3(5,7 \%)$ orang. Dua puluh tujuh 
$(51,9 \%)$ orang mengalami malnutrisi berdasarkan skor SGA. Kondisi malnutrisi didominasi pada usia tua $(71,4 \%)$, jenis kelamin laki-laki $(56,7 \%)$, serangan pertama stroke $(54,5 \%)$, derajat stroke berat $(58,3 \%)$, gejala stroke dengan disfagia $(59,4 \%)$, dengan faktor risiko merokok $(66,7 \%)$ dan memiliki kelainan jantung $(63,6 \%)$, serta dengan komorbid infeksi $(71,4)$ diikuti kondisi lainnya $(62,5 \%)$ dan stress ulcer $(55,6 \%)$.

Dalam penelitian ini didapatkan pada grup usia $\geq 65$ tahun, didominasi oleh kondisi malnutrisi (71.4\%), hal ini disebabkan karena pada usia tua, gejala stroke dapat lebih berat dan memiliki prognosis yang lebih buruk untuk timbulnya malnutrisi. ${ }^{4,10,11}$ Hal tersebut sejalan dengan hasil penelitian dimana malnutrisi didominasi oleh stroke derajat berat $(58,3 \%)$ berdasarkan skor NIHSS. Pada populasi lansia, terdapat beberapa faktor risiko malnutrisi, yaitu dari segi faktor medis (gangguan gastrointestinal, endokrin, infeksi, disabilitas, kanker, disfagia, nafsu makan turun, kehilangan rasa dan penciuman), faktor sosial (kurangnya pengetahuan tentang nutrisi, isolasi dan ketidakmampuan untuk mandiri) serta faktor psikologis (demensia, depresi, dan gelisah). ${ }^{10}$ Kejadian malnutrisi berdasarkan tipe stroke, didominasi oleh grup stroke kardioemboli $(63,6 \%)$, sejalan dengan tingginya angka malnutrisi pada pasien yang memiliki faktor risiko kelainan jantung $(63,6 \%)$. Hal ini sesuai dengan studi lain bahwa stroke infark kardioemboli memiliki hubungan yang signifikan akan munculnya malnutrisi pada fase akut. ${ }^{12}$ Pada studi lainnya dikatakan bahwa serangan stroke yang berulang meningkatkan risiko angka kejadian malnutrisi sebanyak $58-71 \%,{ }^{11}$ namun pada penelitian ini kondisi malnutrisi pada serangan stroke berulang (42,1\%) lebih kecil dibandingkan dengan serangan stroke pertama $(54,5 \%)$. Disfagia dapat berkontribusi akan munculnya malnutrisi pada pasien stroke fase akut, disfagia muncul pada $30-50 \%$ pasien stroke akut dan meningkatkan 12-kali angka kejadian pneumonia aspirasi dan malnutrisi, ${ }^{11}$ dimana pada penelitian ini $61,5 \%$ pasien mengalami disfagia. Namun hal tersebut juga bergantung pada lokasi stroke, gangguan motorik, gangguan persepsi visuospatial, depresi dan gangguan kognisi pasien. Sehingga peran disfagia dalam munculnya malnutrisi masih belum diketahui. Difikirkan pasien disfagia dengan defisit motorik anggota gerak kanan dan dependensi dalam aktivitas sehari-hari menjadi prediksi yang lebih baik untuk angka kejadian malnutrisi. ${ }^{13}$ Kondisi komorbid pada pasien stroke akut dapat menjadi faktor risiko awitan malnutrisi, terutama pasien dengan infeksi, dapat berupa pneumonia, diare akut ataupun ulkus dekubitus. Faktor sebab akibat antara komorbid infeksi dan malnutrisi masih butuh penelitian lebih lanjut. Kondisi malnutrisi yang menyebabkan pasien stroke fase akut rentan terkena infeksi. ${ }^{13,14}$ Hasil laboratorium faktor risiko vaskular pada penelitian ini tidak menunjukkan perbedaan angka dari setiap grup status gizi dan status nutrisi. Setiap grup memiliki rentang angka kejadian dislipidemia yang hampir sama.

\section{Simpulan}

Berdasarkan penelitian ini, gangguan malnutrisi pada stroke fase akut, didominasi pada pasien usia $\geq 65$ tahun, stroke infark kardioemboli derajat stroke sedang-berat berdasarkan skor NIHSS, disertai komorbid terutama infeksi dan stress ulcer. Sehingga, semakin berat derajat stroke disertai komorbid terutama pada usia lanjut membutuhkan perhatian lebih untuk penanganan stroke dengan monitoring dan evaluasi nutrisi yang baik. Riwayat stroke sebelumnya tidak menjadi faktor risiko munculnya malnutrisi pada penelitian ini. Diperlukan penelitian lebih lanjut untuk evaluasi faktor-faktor tersebut yang paling mempengaruhi gangguan nutrisi pada pasien stroke fase akut.

\section{Daftar Pustaka}

1. Penelitian B, Pengembangan dan Riset Kesehatan Dasar. 2014.

2. Feigin VL, Lawes CM, Bennett DA, BarkerCollo SL, Parag V. Worldwide stroke incidence and early case fatality reported in 56 population-based studies: a systematic review. Lancet Neurol. 2009;8(4):355-69 
3. Mozaffarian D, Benjamin EJ, Go AS, Arnett DK, Blaha MJ, Cushman M, et al. Heart disease and stroke statistics-2016 update: a report from the American Heart Association. Circulation. 2016;133(4):e38-360.

4. Bouziana SD, Tziomalos K. Malnutrition in patients with acute stroke. Journal of Nutrition and Metabolism 2011;1-7.

5. Goldstein L. Guideline for the primary prevention of stroke. A guideline for health care professionals from the American Heart Association. American Stroke Association. 2014.

6. Young J, Forster A. Review of stroke rehabilitation. BMJ. 2007;334:86-90.

7. Gomes F, Emery PW, Weekes CE. Risk of malnutrition is an independent predictor of mortality, length of hospital stay, and hospitalization costs in stoke patients. Journal of Stroke and Cerebrovascular Diseases. 2016;25(4):799-806

8. Amalia L, Arsanti F, Megawati G. Hubungan luaran subjective global assessment (SGA) dengan derajat keparahan stroke. Neurona 2019; 36(3):170-75.
9. Obara H, Ito N, Doi M. Nutrition and critical care in very elderly stroke patients. Diet and Nutrition in Critical Care, 2015;753-66.

10. Sabbouh T, Torbey M. Malnutrition in stroke patients: risk factors, assessment, and management. Neurocritical Care, 29(3),2017;374-84.

11. Yoo S, Kim JS, Kwon SU, Yun S, Koh J, Kang D. Undernutrition as a predictor of poor clinical outcomes in acute ischemic stroke patients. Archives of Neurology, 2008;65(1).

12. Norine FC, Ruth ME, Katherine SL, Robert TW. A review of the relationship between dysphagia and malnutrition following stroke. A review of the relationship between dysphagia and malnutrition following stroke. Rehabil Med 2009;4:1707-13.

13. Dávalos A, Ricart W, Gonzalez-Huix F, Soler S, Marrugat J, Molins A, Genís D. Effect of malnutrition after acute stroke on clinical outcome. Stroke 1996; 27(6):1028-032. 